\title{
Pengembangan dan Pelestarian Produk Budaya Udeng Kota Batu
}

\author{
Shannaz Mutiara Deniar'), Yeyen Pratika ${ }^{2)}$ \\ Program Studi Hubungan Internasional, Universitas Muhammadiyah Malang ${ }^{1)}$ \\ Program Studi Manajemen, Universitas Muhammadiyah Malang ${ }^{2)}$ \\ Jalan Tlogomas No. 246 Malang, Jawa Timur, Indonesia \\ Email: yeyenpratika@umm.ac.id
}

\begin{abstract}
ABSTRAK
Kota Batu merupakan salah satu destinasi wisata di Indonesia. Selain destinasi wisata yang sangat beragam, Kota Batu juga memiliki ciri khas budaya yang sangat erat dengan masyarakat sehingga dapat dijadikan identitas. Untuk itu, pengabdian masyarakat ini berfokus pada pengembangan dan pelestarian produk budaya yang terdapat di Kota Batu. Mitra dalam pengabdian ini adalah komunitas Paguyuban Sangga Braja. Paguyuban ini memiliki kepedulian sangat tinggi pada produk budaya, terutama ikat kepala tradisional atau yang dikenal sebagai udeng. Udeng yang didesain oleh paguyuban ini didasari pada sejarah, filosofi, topografi dan kearifan loal Kota Batu. Walaupun Udeng Kota Batu telah mendapat pengakuan dari pemerintah setempat namun informasi dan kesadaran masyarakat mengenai budaya lokal terutama produk budaya udeng Kota Batu ini masih sangat kurang. Padahal, mitra memiliki harapan produk ini dapat dijadikan ciri khas Kota Batu sebagai kota wisata yang memiliki identitas budaya. Untuk mengatasi permasalahan tersebut, solusi yang ditawarkan adalah digitalisasi motif kain batik udeng dan pendaftaran $H K I$.
\end{abstract}

Kata kunci: budaya, digitalisasi, Kota Batu, pemasaran, udeng

\begin{abstract}
Batu City is one of the tourist destinations in Indonesia. In addition to very diverse tourist destinations, Batu City also has cultural characteristics that are very close to the community so that it can be used as an identity. For this reason, this community service focuses on the development and preservation of cultural products found in Batu City. This program associates with the Paguyuban Sangga Braja. This association has a very high concern for cultural products, especially the traditional headband or known as udeng. Udeng designed by the community is based on the history, philosophy, topography and local wisdom of Batu City. Although this udeng has received recognition from the local government, but the information and public awareness about this udeng is still very lacking. In fact, this association expects that this product can be used as a characteristic of Batu City as a tourist city that has a cultural identity. To overcome this problem, the solution offered is to digitalize this batik pattern of udeng and the registration for copyright.
\end{abstract}

Keywords: cultural, digitalization, Batu City, marketing, udeng 


\section{Pendahuluan}

Kota Batu yang berlokasi di provinsi Jawa Timur merupakan kota wisata yang cukup terkenal di Indonesia. Kota Batu memiliki jenis wisata yang sangat beragam, mulai dari wisata alam, wisata buatan hingga wisata sejarah dan budaya. Sebagai kota dengan jumlah wisata alam dan buatan yang tinggi, Kota Batu populer di kalangan wisatawan domestik maupun internasional. Sementara itu, dari aspek wisata dan budaya, Kota Batu juga memiliki peninggalan sejarah yang masih terjaga dengan baik hingga saat ini, seperti Candi Songgoriti. Berdasarkan sejarah yang ada, Candi Songgoriti dan Gunung Panderman yang terletak di Kota Batu menyimpan nilai historis yang sangat melekat pada masyarakat di area Malang Raya, Singosari dan Kota Batu sendiri, terutama pada masa Kerajaan Kahuripan.

Kota Batu sudah memiliki city branding dengan tagline-nya "Shining Batu", namun pengembangan dan penguatan city branding ini hanya terfokus pada pengembangan pariwisata. Padahal, sebuah kota dinilai memiliki city branding yang baik apabila menekankan pada manajemen kota yang dibentuk melalui inovasi strategis dan koordinasi ekonomis, sosial, komersial, budaya dan pemerintah (Anholt, 2010). Mengacu pada konsep city branding itu sendiri, aspek budaya juga tidak kalah penting. Di sisi lain, pemerintah kota sudah sangat aktif dalam mencirikan kotanya sebagai kota budaya melalui pertunjukan dan festival budaya yang secara rutin digelar setiap tahun. Apalagi komunitas budaya juga sangat berkembang dan aktif menjaga kelestarian budaya lokal yang bersinergi dengan Dinas Pariwisata dan Kebudayaan setempat. Sehingga, program pengabdian ini bertujuan untuk menguatkan aspek budaya tersebut di dalam city branding Kota Batu.

Aset sejarah dan budaya yang dimiliki Kota Batu tersebut membentuk kepedulian pada masyarakat lokal Kota Batu dengan secara mandiri mendirikan berbagai komunitas atau paguyuban budaya yang sesuai dengan peminatan masing-masing. Salah satu paguyuban di Kota Batu yang memiliki kepedulian sangat tinggi pada budaya setempat adalah Paguyuban Sangga Braja. Paguyuban ini bermula dari beberapa orang yang memiliki kecintaan pada tosan aji, senjata pusaka tradisional, seperti keris. Awalnya paguyuban ini ingin memecah pandangan masyarakat tentang keris dari hal-hal mistis dan klenik. Namun tujuan paguyuban ini pun meluas dan berkembang seiring dengan bertambahnya anggota dan kemudian menjadi wadah berkumpulnya para pecinta dan pemerhati budaya lokal Kota Batu.

Terbentuk secara resmi pada tahun 2017, Paguyuban Sangga Braja memulai misinya untuk melestarikan budaya dan nilai-nilai lokal di masyarakat yang semakin tergerus oleh modernitas. Salah satu upaya paguyuban ini dalam mengembangkan budaya Kota Batu adalah dengan menciptakan satu produk budaya berupa udeng atau ikat kepala yang memiliki ciri khas Kota Batu. Berbeda dengan udeng yang berasal dari kota lainnya, udeng Kota Batu didesain dengan mengangkat hal-hal yang berbasis kearifan lokal Kota Batu. Atas dasar hal tersebut, konsep, bentuk dan motif kain udeng ini menekankan pada filosofi Kota Batu, yakni bentuknya yang menggambarkan topografi Kota Batu dan motif batik yang digunakan memiliki makna yang bersumber pada kebudayaan Jawa. Udeng khas Kota Batu yang diciptakan oleh paguyuban ini sudah mendapat pengakuan dari pemerintah dan komunitas budaya lokal, serta menjadi satusatunya ikat kepala tradisional yang dikenal di Kota Batu. Meskipun saat ini udeng Kota Batu tersebut telah mendapatkan dukungan dari pemerintah setempat berupa kewajiban menggunakan udeng sebagai atribut kerja pada hari-hari tertentu, namun udeng masih terbatas penggunaannya di kalangan paguyuban dan pemerintah kota setempat saja. Selain itu, keaktifan paguyuban dalam mengikuti pameran seni dan budaya Kota Batu juga belum cukup mendorong adanya peningkatan kesadaran masyarakat, khususnya warga Kota Batu sendiri terkait udeng ini. 


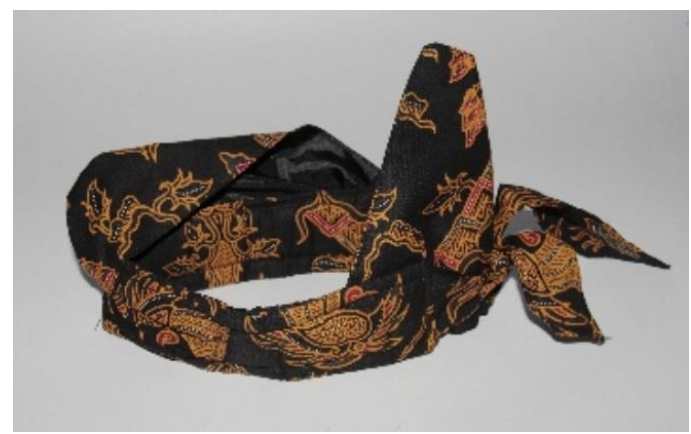

Gambar 1. Udeng Khas Kota Batu

Bentuk udeng khas Kota Batu ini sudah memiliki hak cipta sejak tahun 2019. Selain memberi perlindungan dari hasil kreativitas dan karya intelektual, pendaftaran HKI bentuk udeng khas Kota Batu juga memberikan keuntungan ekonomis (Deniar, Pratika, \& Effendi, 2021). Udeng Kota Batu ini sebenarnya juga memiliki kekhasan lain selain bentuk dan modelnya, yaitu motif kain batiknya yang sangat khas dan menggambarkan nilai-nilai filosofi masyarakat setempat. Motif ini adalah hasil kreasi anggota paguyuban yang menyesuaikan dengan jiwa dan ruh dari Kota Batu. Mitra merasa bahwa perpaduan antara bentuk dan motif kain batik yang sesuai dengan kreasi ini akan dapat memberikan ciri khas yang lebih optimal bagi identitas udeng khas Kota Batu tersebut. Untuk itu, pendaftaran HKI atas motif kain batik ini juga dinilai sangat penting untuk menjaga dan melindungi kreativitas yang telah dilakukan oleh paguyuban ini. Sehingga, salah satu program yang juga ditekankan dalam pengabdian ini adalah pendampingan pendaftaran HKI atas motif kain batik tersebut.

Sejak diperkenalkan pada tahun 2018, paguyuban sering menggunakan kain batik ini pada saat mempromosikan udeng. Namun, paguyuban merasa cukup kesusahan karena tidak memiliki blueprint atau desain atau rancangan standar dari motif batik sehingga hanya memiliki satu contoh kain saja. Pada setiap kegiatan, paguyuban akhirnya sering menggunakan kain ini dengan resiko kerusakan pemakaian menjadi tinggi. Dengan tidak adanya desain atau rancangan, identitas dari setiap goresan motif batik ini juga akhirnya menjadi terabaikan. Motif batik ini sangat potensial untuk terus dilestarikan dan dikenalkan kepada khalayak. Untuk itu, solusi yang ditawarkan pada aspek pemasaran yakni dengan mendigitalisasi motif batik yang digunakan sebagai udeng khas Kota Batu.

Digitalisasi merupakan proses pemindahan data atau bentuk dari yang non-digital menjadi digital. Di dalam pemasaran, proses digitalisasi ini sangat dibutuhkan untuk meningkatkan efisiensi, efektivitas dan produktifitas yang nantinya dalam memberikan keuntungan yang lebih optimal bagi perusahaan (Dwivedi et al., 2020). Digitalisasi motif batik ini sangat dibutuhkan agar mitra dapat mudah dalam meningkatkan jumlah produksi dan juga memudahkan dalam hal proses promosinya. Saat ini, mitra masih belum konsisten dalam memproduksi udeng dengan motif kain batik yang menjadi ciri khasnya karena keterbatasan waktu dan pengrajin yang mampu membatik ulang dengan motif yang sama. Selain itu, dari aspek pemasaran, digitalisasi ini akan memudahkan proses identifikasi produk sehingga dapat meningkatkan kesadaran konsumen atas merek atau produk yang dihasilkan oleh mitra. Melalui proses digitalisasi ini juga dapat membantu mitra dalam pemasarannya yang saat ini sedang dalam proses pengembangan untuk menuju pemasaran online.

\section{Tinjauan Pustaka}

Kemunculan pendekatan pemasaran berbasis teknologi dikenal dengan pemasaran digital (Nuseir \& Aljumah, 2020). Digitalisasi telah menadi bagian penting di berbagai industri. Hal ini dikarenakan digitalisasi mampu memberikan pengaruh pada produk dan brand itu sendiri melalui penggunaannya di media digital. Upaya digitalisasi ini seringkali memanfaatkan media digital yang 
digunakan oleh berbagai perusahaan atau organisasi untuk memfasilitasi adanya interaksi partisipasif di antara bisnis, kelompok, organisasi, komunitas dan sejenisnya (Dwivedi, Kapoor, \& Chen, 2015). Selain juga, pemanfaatan ini dinilai mampu mendorong branding yang lebih baik lagi atas sebuah merek. Proses melakukan branding dengan memanfaatkan teknologi digital ini juga dilakukan oleh berbagai kota untuk menekankan city branding-nya.

Pada dasarnya, setiap kota perlu memiliki ciri khas yang dapat membedakan dengan kota lainnya. Hal ini bertujuan agar setiap kota mempunyai identitas yang melekat dan menjadi keunggulan kompetitif dari kota tersebut. Di dalam ilmu pemasaran terdapat konsep mengenai city branding yang mengacu pada proses penerapan praktik pencitraan produk terhadap suatu kota yang bertujuan untuk mengintegrasikan dan menyoroti keunggulan kompetitif melalui citra identitas atau merek yang persisten terkait kota tersebut (Zhang \& Zhao, 2009). Citra produk yang dibangun dalam konsep city branding mengarah pada karakteristik unik yang dimiliki oleh kota tersebut melalui potensi-potensi yang ada baik dari segi ekonomi maupun budaya (Larasati \& Nazaruddin, 2016).

Selama ini, Kota Batu sudah memiliki city branding yang sudah sangat melekat dengan strategi "Shining Batu". Konsep yang disebutkan di atas sudah sangat sejalan dengan apa yang diharapkan oleh mitra mengenai produk budaya udeng yang dapat dijadikan ciri khas atau identitas Kota Batu. Potensi budaya yang dimiliki oleh Kota Batu dengan udeng ini dinilai mampu mendorong citra Kota Batu sebagai kota wisata dari aspek budaya. Pengenalan budaya, hiburan dan kreativitas yang ada di suatu daerah juga memerlukan adanya kegiatan pemasaran agar lebih mudah dikenali oleh masyarakat (Intyaswono, Yulianto, \& Mawardi, 2016). Untuk itu, upaya pengembangan dan pelestarian budaya Kota Batu ini dapat dilakukan melalui aspek pemasaran dan digitalisasi agar masyarakat mudah mengenali udeng khas Kota Batu ini.

\section{Metodologi Pelaksanaan}

Kegiatan pengabdian masyarakat ini dilakukan di Kota Batu melalui kerjasama dengan Paguyuban Sangga Braja. Kegiatan terbagi menjadi beberapa tahap dengan tujuan agar kegiatan pengabdian dapat berjalan dengan maksimal. Adapun rincian mengenai kegiatan tersebut sebagai berikut:

a. Tahap Persiapan

Tahap ini dimulai melalui tim pengabdian melakukan koordinasi dengan Paguyuban Sangga Braja mengenai program kerja yang dibutuhkan mitra atas penyelesain permasalahan yang dihadapi oleh mitra. Dari hasil diskusi dengan mitra, maka aspek pemasaran perlu dilakukan dengan menekankan pada digitalisasi motif batik dan pendampingan pendaftaran HKI yang digunakan pada udeng tersebut. Selama tahap ini, mitra berperan aktif dalam menerjemahkan filosofi baik dari bentuk maupun motif batik yang digunakan sehingga proses mendigitalisasi motif kain batik tersebut dapat terlaksana dengan baik.

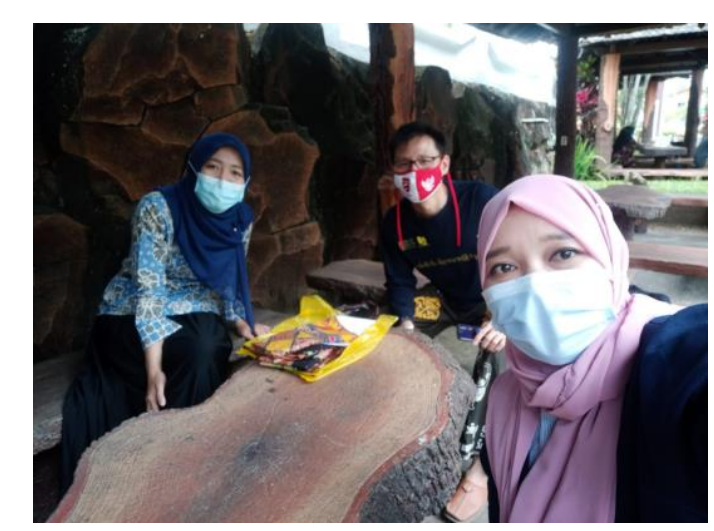

Gambar 2. Koordinasi dengan Ketua Paguyuban Sangga Braja 
b. Tahap Pelaksanaan dan Pendampingan

Pada tahap pelaksanaan terdapat beberapa hal yang dilakukan:

1. Digitalisasi

Pada tahap ini, tim pengabdian mendokumentasikan motif kain batik yang dimiliki oleh paguyuban dalam bentuk digital dengan dibantu oleh seorang ahli. Proses mendigitalisasikan ini sendiri dilakukan dengan menggambar ulang secara digital sesuai bentuk asli, dengan menggunakan perangkat lunak CorelDRAW Graphics Suite 2020. Selain itu, hasil digitalisasi ini digunakan oleh paguyuban untuk mempromosikan produknya serta dikemudian hari digunakan untuk memproduksi kain udeng secara massal.

\section{Pendampingan HKI}

Proses digitalisasi yang dilakukan pada tahap di atas menghasilkan gambar yang selanjutnya digunakan sebagai dokumen untuk mengajukan HKI. Pendampingan yang dilakukan dalam proses pendaftaran HKI ini dimulai dengan dalam mengidentifikasi dokumen-dokumen yang dibutuhkan. Pendaftaran HKI ini diatasnamakan institusi, sehingga dokumen yang harus dilengkapi adalah surat pengalihan hak (dari pembuat karya kepada pemegang hak cipta), NPWP, akta notaris dan fotokopi identitas pemohon dan pencipta karya (KTP), serta dokumen karya. Selanjutnya, proses pendaftaran HKI diwakilkan oleh Sentra HAKI Universitas Muhammadiyah Malang (UMM). Proses pendaftaran HKI ini sendiri hampir sepenuhnya dilakukan secara digital, kecuali pada proses penandatanganan berkas-berkas yang harus dilaksanakan di kantor Sentra HAKI UMM tersebut.

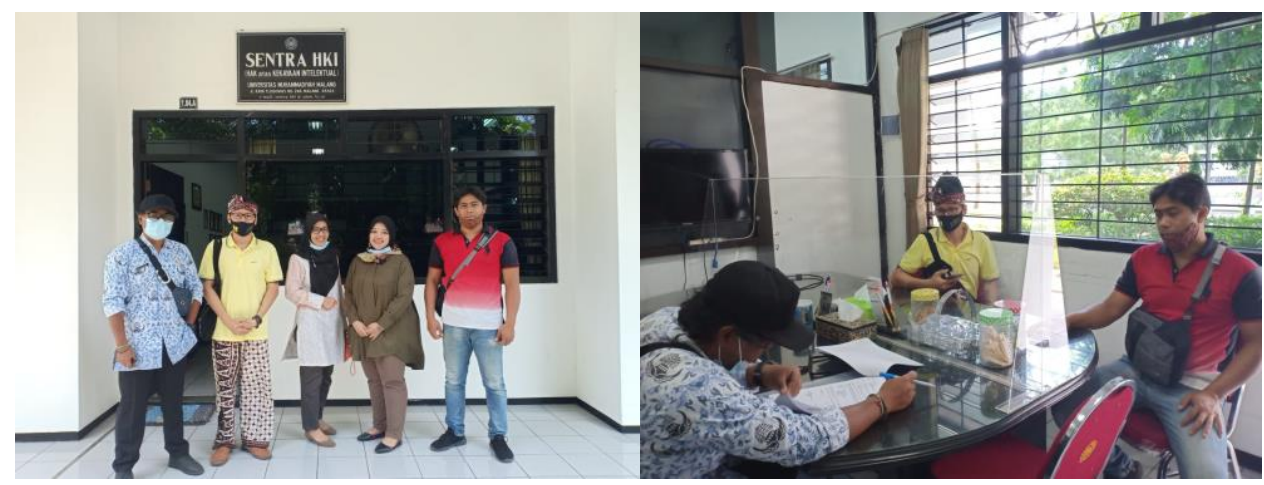

Gambar 3. Proses Pendampingan dalam Pendaftaran HAKI

Pada dasarnya, proses pengurusan hak cipta ini dapat dilakukan secara mandiri melalui situs www.e-hakcipta.dgip.go.id dengan beberapa tahapan yang perlu dilakukan, yaitu a) registrasi, b) mengunggah dokumen persyaratan, c) melakukan pembayaran, d) menunggu proses pengecekan, e) jika pendaftaran ciptaan telah disetujui, sertifikat dapat diunduh sendiri. Namun, untuk meminimalisir resiko kesalahan yang mungkin terjadi, tim pengabdian memutuskan untuk bekerjasama dengan pihak ketiga (Sentra HAKI UMM).

\section{Hasil dan Pembahasan}

Pada pengabdian masyarakat di Kota Batu melalui kerjasama dengan mitra Paguyuban Sangga Braja, tim pengabdian melakukan serangkaian kegiatan dengan hasil yang cukup baik dan sesuai dengan target yang ada. Kegiatan pengabdian ini sendiri dilakukan sejak Februari hingga November 2020. Seperti yang telah disebutkan di atas, tahapan persiapan dimulai melalui koordinasi dengan mitra pengabdian. Pada tahap ini, tim pengabdian melakukan survei, wawancara dan observasi langsung dengan ketua dan beberapa anggota paguyuban guna memperoleh gambaran terkait permasalahan yang mitra hadapi. Hasil koordinasi dan diskusi tersebut mengindikasikan bahwa 
mitra masih memiliki kesulitan dalam aspek pemasaran sehingga perlu didampingi untuk mendigitalisasikan motif batik yang digunakan pada udeng tersebut.

Pada tahap persiapan, peran aktif mitra dalam menjelaskan filosofi dan makna bentuk dan motif batik sangat membantu sekali dalam proses digitalisasi motif kain batik tersebut. Hal ini agar hasil digitalisasi motif batik tersebut dapat sesuai dengan motif aslinya sehingga tidak menyimpang dari filosofi dan makna yang mendasari motif tersebut yang dapat dilihat pada Gambar 4 dan 5 . Kelebihan dengan mendigitalisasikan motif batik ini adalah agar mitra lebih mudah mempromosikan udeng khas Kota Batu ini dengan ciri khas motif batiknya yang juga berbeda dengan udeng-udeng dari kota lainnya. Solusi ini juga akan memudahkan mitra dalam memproduksi udeng secara massal dengan motif yang sama agar lebih terstandardisasi. Selain itu hasil digitalisasi ini juga akan sangat berguna dalam produksi dalam hal efisiensi dan efektifitas karena motif ini dapat dicetak dengan proses pencetakan yang hasilnya lebih murah dan cepat.

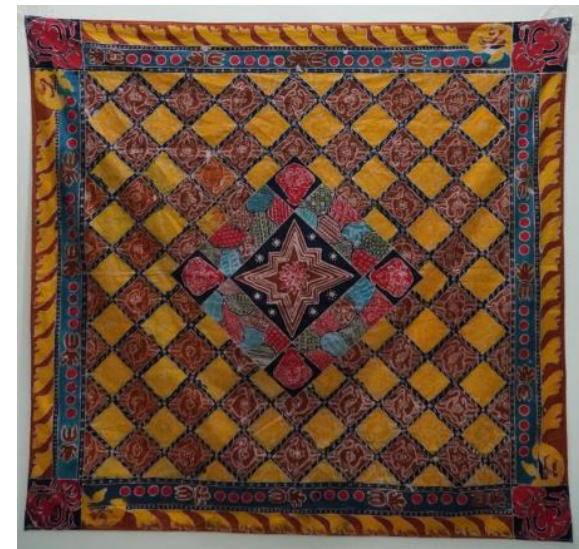

Gambar 4. Motif Kain Batik Asli

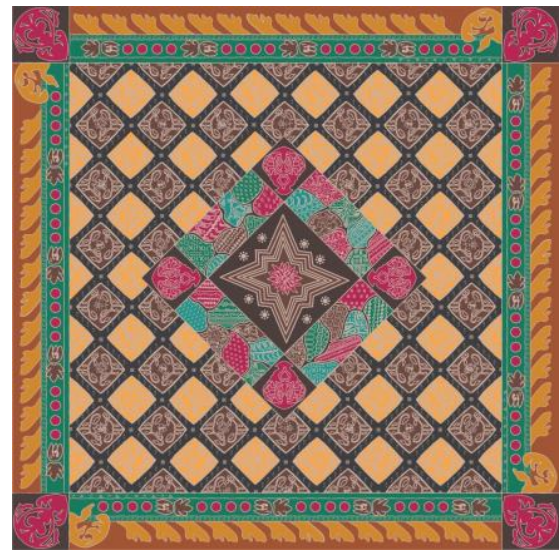

Gambar 5. Motif Kain Batik Hasil Digitalisasi

Pada tahap pelaksanaan dan pendampingan, mitra yang terdiri dari ketua dan anggota dan tim pengabdian mengadakan diskusi dengan sentra HAKI yang ada di Universitas Muhammadiyah Malang. Tujuan dari hal ini adalah sekaligus sebagai pendampingan mengenai proses dan syarat pemenuhan pada pendaftaran hak kekayaan intelektual (HKI). Pada tahap ini, mitra tentunya aktif terlibat dalam proses tersebut sementara tim pengabdian mendampingi hingga sertifikat hak cipta atas motif batik yang diajukan terbit dari Kementerian Hukum dan Hak Asasi Manusia.

Pendaftaran HKI dimaksudkan untuk memberi perlindungan karya kreativitas dan intelektual dari Paguyuban Sangga Braja sebagai pencipta. Bentuk ciptaan pengetahuan dan teknologi yang dibuat oleh masyarakat pada pada praktek paten atau pendaftaran HKI belum mampu melindungi pengetahuan tradisional (Tuuk, 2017). Sebagai pencipta, individu, kelompok atau komunitas sering terabaikan padahal di lain sisi upaya komersialisasi teknologi masyarakat terus meningkat. Sebagai upaya perlindungan ekspresi budaya, promosi kreatifitas, dan pelestarian warisan budaya, pendaftaran motif batik udeng khas Kota Batu ini menjadi penting.

Di era saat ini, hak cipta dan hak merek merupakan aset bisnis bagi usaha kecil dan menengah (Budiman \& Dialog, 2019). Pendaftaran HKI penting karena ini membentuk sebuah citra bagi organisasi/perusahaan. Dalam hal ini, paguyuban Sangga Braja memang perlu mendaftarkan HKI atas motif kain batik yang digunakan agar visualisasi citra dari udeng khas Kota Batu yang diinisiasi oleh paguyuban ini dapat terbentuk. Penguatan visualisasi yang menampilkan karakter dari suatu merek penting untuk dibentuk, dikelola, dikembangkan, dan dioptimalkan dengan tujuan agar konsumen/masyarakat memahami kekuatan citra/branding (Prasetyo \& Febriani, 2020). Sehingga, urgensi pendaftaran HKI motif kain batik dalam program pengabdian ini sangat perlu direalisasikan agar citra udeng sebagai hasil budaya lokal dapat tercipta. 
Kolaborasi dan partisipasi aktif dari mitra ditunjukkan dengan sangat antusias. Mitra merasa hasil digitalisasi ini sangat bermanfaat bagi pemasaran udeng Kota Batu selanjutnya dan berharap masyarakat Kota Batu menjadikan udeng ini dalam kegiatan mereka sehari-hari. Tim pengabdian merasa perlu untuk terus mendampingi mitra dalam mewujudkan cita-cita tersebut, untuk itu kami berharap dapat melanjutkan program pengabdian mengenai pemanfaatan atas hasil digitalisasi yang telah dilakukan ini.

\section{Daftar Pustaka}

Anholt, S. (2010). Places: Identity, Image and Reputation (1st ed.). London: Springer.

Budiman, H., \& Dialog, B. L. (2019). Sosialiasi Hak Cipta Dan Hak Merek Pada Kelompok Usaha Kecil Dan Menengah (Ukm) Sebagai Aset Bisnis Di Era Industri Kreatif. Empowerment: Jurnal Pengabdian Masyarakat, 2(02), 94-100. https://doi.org/10.25134/empowerment.v2i02.2109

Deniar, S. M., Pratika, Y., \& Effendi, T. D. (2021). Pendampingan dan Pengembangan Produk Udeng Sangga Braja dalam Rangka Melestarikan Ciri Khas Kota Batu. Abdimas: Jurnal Pengabdian Masyarakat Universitas Merdeka Malang, 6(2), 166-175. https://doi.org/10.26905/abdimas.v6i2.5171

Dwivedi, Y. K., Ismagilova, E., Hughes, D. L., Carlson, J., Filieri, R., Jacobson, J., ... Wang, Y. (2020). Setting the future of digital and social media marketing research: Perspectives and research propositions. International Journal of Information Management, (May). https://doi.org/10.1016/j.ijinfomgt.2020.102168

Dwivedi, Y. K., Kapoor, K. K., \& Chen, H. (2015). Social media marketing and advertising. The Marketing Review, 15(3), 289-309.

Intyaswono, S., Yulianto, E., \& Mawardi, M. K. (2016). Peran Strategi City Branding Kota Batu dalam Trend Peningkatan Kunjungan Wisatawan Mancanegara. Jurnal Administrasi Bisnis, 30(1), 65-73. Retrieved from administrasibisnis.studentjournal.ub.ac.id\%0A

Larasati, D., \& Nazaruddin, M. (2016). Potensi Wisata Dalam Pembentukan City Branding Kota Pekanbaru. Jurnal Komunikasi, 10(2), 99-116. https://doi.org/10.20885/komunikasi.vol10.iss2.art1

Nuseir, M. T., \& Aljumah, A. (2020). The role of digital marketing in business performance with the moderating effect of environment factors among SMEs of UAE. International Journal of Innovation, Creativity and Change, (3), 310-324.

Prasetyo, B. D., \& Febriani, N. S. (2020). Strategi Branding: Teori dan Perspektif dalam Komunikasi Bisnis. Malang: UB Press.

Tuuk, W. P. (2017). Perlindungan Hak Kekayaan Intelektual (HKI) terhadap Pengetahuan dan Teknologi Tradisional Menurut Undang-Undang Nomor 13 Tahun 2016 tentang Paten. Lex Privatum, 5(4).

Zhang, L., \& Zhao, S. X. (2009). City branding and the Olympic effect: A case study of Beijing. Cities, 26(5), 245-254. https://doi.org/10.1016/j.cities.2009.05.002 